\section{Armillaria root rot in seeded and planted areas in Newfoundland}

\author{
PRITAM SINGH and J. RICHARDSON
}

\author{
Canadian Forestry Service \\ Newfoundland Forest Research Centre \\ St. John's, Newfoundland
}

\begin{abstract}
Le pourridié-agaric dans les bâches de semis et les superficies reboisées à Terre-Neuve. La présence du pourridiéagaric variait selon la méthode de plantation utilisée. Ainsi, la présence du champignon fut plus importante lors de plantations effectuées à racines nues comparativement au taux enregistré par l'emploi des godets ou par ensemencement. De plus, ce phénomène se remarquait davantage sur les tiges exotiques que sur les conifères auto. chtones.
\end{abstract}

Recent and predicted increases in wood requirements are causing concern that the forests of Newfoundland will not satisfy the needs of industry. It is expected that if demands are to be met every productive area must be reforested immediately following cutting or any other disturbance. During recent years the Canadian Forestry Service experimented with different methods of planting and seeding to determine the best procedures for reforesting non-regenerating cutover and burned areas on the Island.

During these studies it has been observed that Armillaria root rot, caused by Armillaria mellea (Vahl ex Fr.) Kummer, is probably the most important disease affecting man-made forest in Newfoundland (Warren and Singh 1968, 1969 and 1970; Clark and Singh 1970; Hall et al. 1971). The fungus is a soil borne saprophyte but it can become a primary pathogen on roots and stems of a wide variety of plants. It kills trees by destroying the cambium of the roots and lower bole. The fungus is recognized by white or creamy mycelial fans under the bark, by the presence of black or dark brown rhizomorphs under the bark or in the adjacent soil, or by the occurrence of honey-colored fruiting bodies at or near the base of trees.

This paper presents results of surveys conducted between 1968 and 1971 to compare the intensity of F.rmillaria root rot in a number of stands artificially established by seeding and planting a variety of species. Pertinent characteristics of each study area and mode of establishment are shown in Table 1; locations are shown in Fig. 1.

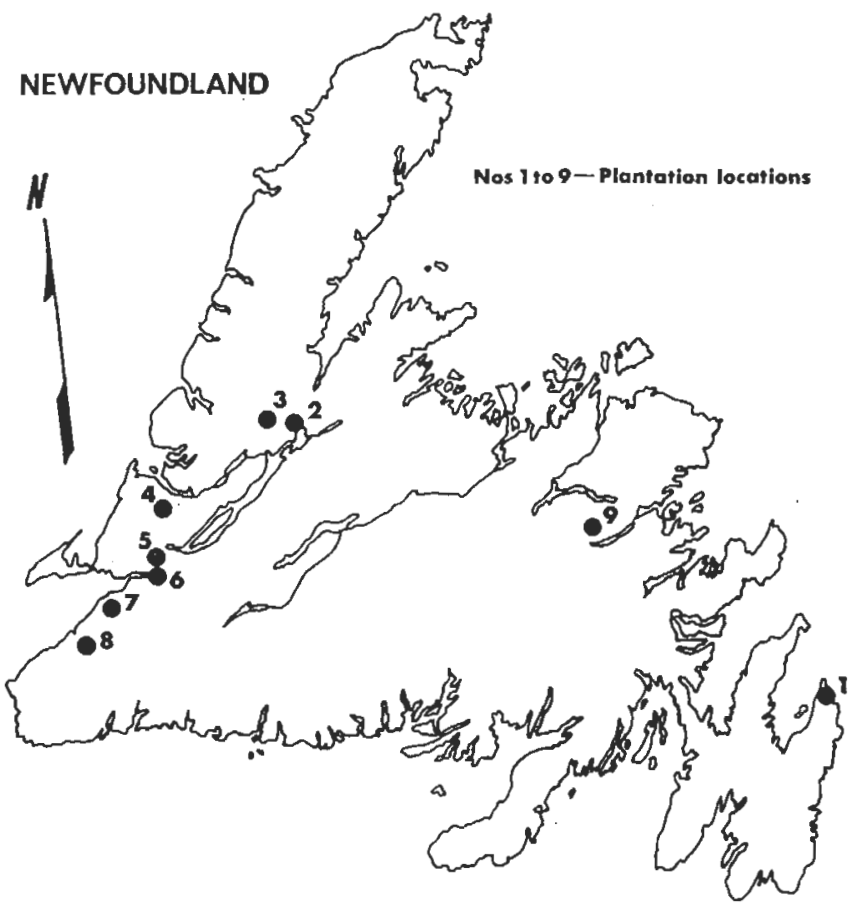

Fig. 1. Map of Newfoundland showing lacation of plantations.

\section{Methods}

The intensity of sampling in plantations was as follows: every chlorotic and dead tree, and approximately $10 \%$ of the apparently healthy trees at Bauline Line, Cormack, Stephenville, Bottom Brook, Middle Brook and Highlands River; every tree encountered at North Pond; and a constant number of trees in 18 subplots in the plantation at Serpentine Lake. On areas where seed was sown on prepared seed spots, every tree on randomly selected spots was examined as were all trees in equally spaced milacre quadrats established in areas where seeds were broadcast. A total of 5,640 trees in areas established by bare root stock, 159 trees in areas established by container stock, 1,175 trees in areas established by seed spotting, and 2,121 trees in areas established by broadcast seeding were examined.

Examination of seedlings consisted of an inspection of the primary and secondary roots, and the root collar for symptoms of the disease and signs of the pathogen. Isolations from mycelial fans and rhizomorphs were made on $2 \%$ malt agar to confirm the identity of the fungus. Incidence of the disease was expressed as a percentage of the total noumber of trees examined.

Data were aiso collected from all study areas on the physiographic site conditions, soil texture and $\mathrm{pH}$, mode of establishment of plantations and the numbers of stumps per acre infected with $A$. mellea (Table 1). 
TABLE 1. Location, size, site, soil characteristics and mode of establishment of areas, and number of infected stumps

\begin{tabular}{|c|c|c|c|c|c|c|c|}
\hline No. & Location & $\begin{array}{l}\text { Total } \\
\text { area } \\
\text { (acres) }\end{array}$ & $\begin{array}{l}\text { Physiographic } \\
\text { site }\end{array}$ & $\begin{array}{l}\text { Soil } \\
\text { textural } \\
\text { class }\end{array}$ & $\begin{array}{l}\text { Soil } \\
\text { pH }\end{array}$ & $\begin{array}{l}\text { Stumps/acre } \\
\text { infected } \\
\text { with } \\
\text { A. mellea }\end{array}$ & $\begin{array}{l}\text { Mode of } \\
\text { establishment }\end{array}$ \\
\hline 1. & Bauline Line $(1)^{4}$ & 3.2 & $\begin{array}{l}\text { Moist to wet heathland } \\
\text { with a few dry patches }\end{array}$ & Clay loam & 4.9 & 5.6 & Bare root \\
\hline $\begin{array}{l}2 . \\
3 . \\
4 .\end{array}$ & $\begin{array}{l}\text { Birchy Lake (1) } \\
\text { Cormack (1) } \\
\text { Serpentine Lake (1) }\end{array}$ & $\begin{array}{r}15.4 \\
1.4 \\
9.6 \\
4.8\end{array}$ & $\begin{array}{l}\text { Fresh to wet } \\
\text { Fresh } \\
\text { Fresh } \\
\text { Fresh }\end{array}$ & $\begin{array}{l}\text { Sandy loam } \\
\text { Loam } \\
\text { Loam } \\
\text { Loam }\end{array}$ & $\begin{array}{l}4.3 \\
4.8 \\
4.8\end{array}$ & $\begin{array}{r}0.7 \\
528.7 \\
3.5 \\
3.5\end{array}$ & $\begin{array}{l}\text { Seedspotting } \\
\text { Bare root } \\
\text { " " } \\
\text { Seeding (Seedspotting }\end{array}$ \\
\hline 5. & Stephenville (1) & 2.5 & Fresh with a few patches & Loam & 4.7 & 23.8 & Bare root \\
\hline $\begin{array}{l}6 . \\
7 . \\
8 . \\
9 . \\
9 . \\
\text { a }\end{array}$ & $\begin{array}{l}\text { Bottom Brook (1) } \\
\text { Middle Brook (1) } \\
\text { Highlands River (1) } \\
\text { North Pond (2) } \\
\text { North Pond (3) }\end{array}$ & $\begin{array}{l}0.3 \\
0.3 \\
0.3 \\
4.3 \\
2.5\end{array}$ & $\begin{array}{l}\text { Fresh } \\
\text { Moist to very moist } \\
\text { Dry } \\
\text { Fresh to moist } \\
\text { Dry to wet (mostly } \\
\text { fresh to moist) }\end{array}$ & $\begin{array}{l}\text { Sandy loam } \\
\text { Loam } \\
\text { Loam } \\
\text { Sandy loam } \\
\text { Stony clay }\end{array}$ & $\begin{array}{l}4.5 \\
4.6 \\
4.4 \\
4.3 \\
4.3\end{array}$ & $\begin{array}{r}1105.5 \\
1083.6 \\
694.5 \\
154.3 \\
903.8\end{array}$ & $\begin{array}{c}" \bar{"} \\
", " \\
\text { Container } \\
\text { Seedspotting }\end{array}$ \\
\hline $\mathfrak{c}$ & North pond (4) & 202.2 & $\begin{array}{l}\text { Fresh to wet (mostly } \\
\text { fresh to moist) }\end{array}$ & Sandy loam & 4.3 & 758.9 & Broadcast seeding \\
\hline
\end{tabular}

The numbers in parentheses indicate the number of plantations examined in that area.

"Two types of containers used in the two plantations: $9 / 16^{\prime \prime}$ diam. high impact polystyrene tubes and 3 " long plastic bullets.

TABLE 2. Incidence of Armillaria root rot in four Picea species by mode of establishment Planting

Direct seeding

Bare root Container Seedspot Broadcast

\begin{tabular}{|c|c|c|c|c|c|c|c|c|}
\hline Species & $\begin{array}{c}\text { No. of } \\
\text { trees } \\
\text { examined }\end{array}$ & $\stackrel{\%}{\%}$ & $\begin{array}{l}\text { No. of } \\
\text { trees } \\
\text { examined }\end{array}$ & $\begin{array}{c}\% \\
\text { Infection }\end{array}$ & $\begin{array}{c}\text { No. of } \\
\text { trees } \\
\text { examined }\end{array}$ & $\begin{array}{c}\% \\
\text { Infection }\end{array}$ & $\begin{array}{l}\text { No. of } \\
\text { trees } \\
\text { examined }\end{array}$ & $\begin{array}{c}\% \\
\text { Infection }\end{array}$ \\
\hline glauca and $P$. mariana & 2,936 & 5.1 & & & 1,000 & 0 & 1,302 & 0.1 \\
\hline abies... & 425 & 12.5 & & & 122 & 1.4 & & \\
\hline sitchensis . . & 961 & 31.8 & 159 & 0 & 30 & 0 & 633 & 0.3 \\
\hline
\end{tabular}

TABLE 3. Incidence of Armillaria root rot in different species established by bare root planting ${ }^{\mathrm{a}}$

$\begin{array}{cccc}\text { Species } & \begin{array}{c}\text { No. of } \\ \text { plantations } \\ \text { examined }\end{array} & \begin{array}{c}\text { No. of } \\ \text { trees } \\ \text { examined }\end{array} & \%\end{array}$

Native ${ }^{\mathrm{b}}$

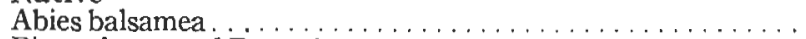

Picea glauca and P. mariana . . . . . . .

Pinus resinosa. .

$\begin{array}{lr}3 & 125 \\ 2 & 2,936 \\ 1 & 337 \\ 6 & 3,398\end{array}$

Exotic

Abies holophylla.

Abies homolepis. . . . . . . . . . . . . . . . . . . . . . .

Abies marièsii . . . . . . . . . . . . .

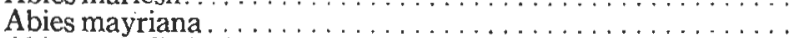

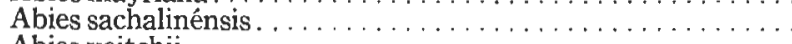

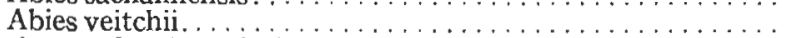

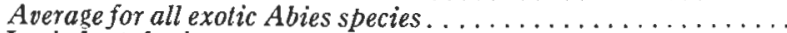

Larix leptolepis . . . . . . . . . . . . . . . . . . . . .

Picea abies.

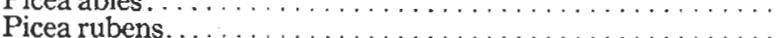

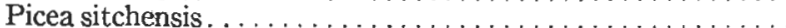

Average for all exotic Picea species . . . . . . . . . . . . . . .

Pseudotsuga menziesii.

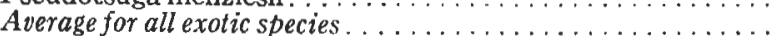

Exotic crossed with native

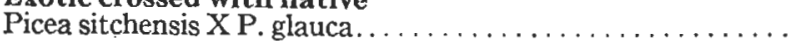

$$
\begin{aligned}
& 3 \\
& 3 \\
& 3 \\
& 3 \\
& 3 \\
& 3 \\
& 3 \\
& 1 \\
& 2 \\
& 1 \\
& 3 \\
& 3 \\
& 1 \\
& 6
\end{aligned}
$$

$\begin{array}{rr}62 & 79.0 \\ 83 & 32.5 \\ 91 & 28.8 \\ 49 & 32.7 \\ 69 & 34.8 \\ 297 & 16.7 \\ 651 & 29.5 \\ 66 & 4.5 \\ 425 & 12.5 \\ 41 & 1.8 \\ 961 & 31.8 \\ 1,427 & 25.2 \\ 85 & 30.5 \\ 2,229 & 26.0\end{array}$

1
15.2

anly data from bare root planting is used because the incidence of the disease was very low for the other establishment methods.

These species occur naturally on the Island but all planting stock was introduced from the Acadia Forest Experiment Station, New Brunswick. 


\section{Results and discussion}

Armillaria mellea occurred in a wide range of soil conditions and in locations with varying numbers of infected stumps, indicating that the disease increased with an increase in the number of infected stumps, particularly where plantations were established with bare root stock (Table 1 ).

Results of the investigations show that the incidence of Armillaria root rot varied considerably between species and modes of establishment. Armillaria root rot was present in all plantations established with bare root stock. It was also present on some seedlings in some seeded areas but was absent on seedlings established by the container method. In areas planted with bare root seedlings the infection averaged $17.8 \%$, in seedspotted areas $1.1 \%$, and in broadcast seeded areas only $0.2 \%$. A total of 17 species were examined during the surveys but only 4 species (Picea glauca, $P$. mariana, $P$. abies and $P$. sitchensis) had been established by more than one method. Data for these four species show that percent infection ranged from 5.1 to $31.8 \%$ for bare root planting, $0 \%$ for container planting, 0 to $1.4 \%$ for seedspotting, and 0.1 to $0.3 \%$ for broadcast seeding (Table 2). All of these results suggest that regardless of species and the number of infected stumps, trees in plantations established with bare root stock are much more susceptible to attack by $A$. mellea than those established by container planting or by direct seeding.

The results also indicated that exotic species are more susceptible to the disease than are native species. For example, infection in exotic firs averaged $29.5 \%$ as compared to $4.8 \%$ for the native fir, and exotic spruces averaged $25.2 \%$ as compared to $5.1 \%$ for native spruces. Average infection for all exotics was $26.0 \%$ while that for all native species was $4.9 \%$ (Table 3 ).

On the basis of these results, it would appear that to avoid losses by Armillaria root rot in Newfoundland non-stocked areas should be regenerated by seeding or perhaps container planting. It also seems apparent that native species should be used. Richardson (1970 a, 1970 b, 1972) has demonstrated that good stands can be produced by seeding native stock. On areas with an organic mantle more than about 2 inches deep scarification is required prior to seeding.

\section{References}

CLARK, R. C. and PRITAM SINGH. 1970. Important forest diseases. In Annual report of the forest insect and disease survey, p. 11-18. Can. Dep. Fish. Forest., Can. Forest. Serv., Ottawa.

HALL, J. PETER, PRITAM SINGH and H. O. SCHOOLEY. 1971. Survival and growth of some exotic firs in Newfoundland. Forest. Chron. 47: 279-281.

RICHARDSON, J. 1970a. Broadcast seeding black spruce on a burned cutover. Can. Dep. Fish. Forest, Can. Forest Serv., Publ. No. 1272. 14 p.

1970 b. Broadcast seeding a burned cutover after light scarification. Can. Dep. Fish. Forest., Can. Forest. Serv., Inform. Rep. N-X-58. 21 p.

1972. Seedspotting black spruce throughout the growing season. Can. Dep. Environ., Can. Forest. Serv., Inform. Rep. N-X-69. 16 p.

WARREN, G. L. and PRITAM SINGH. 1968. Important forest diseases. In Annual report of the forest insect and disease survey, Newfoundland Region, p. 10-17. Can. Dep. Fish. Forest., Can. Forest. Service, Ottawa.

1969. Important forest diseases. In Annual report of the forest insect and disease survey, Newfoundland Region, p. 10-19. Can. Dep. Fish. Forest., Can. Forest. Serv., Ottawa.

1970. Hylobius weevils and Armillaria root rot in a coniferous plantation in Newfoundland. Bi-Monthly Res. Notes, 26: 55. 